\title{
GROUND-BASED REMOTE SENSING FOR ESTIMATING THE MOISTURE CONTENT OF DIFFERENT SOIL TYPES
}

\author{
Elsayed, S. ${ }^{(1)}$ and M. I. Ghazy ${ }^{(2)}$
}

\begin{abstract}
Soil moisture information has been used for irrigation scheduling, sitespecific management of diseases and pests, and improving crop yield prediction. Spectral remote sensing offers the potential to provide more information for making better-informed management decisions in real time. In contrast, the tradition methods for irrigation management such as tensiometers and oven dry for estimating moisture content are generally time consuming, numerous observations are required to characterize them. The aim of this study was to investigate the suitability of hyperspectral reflectance sensor to estimate the moisture content of different soils. For that the spectral indices of soil were tested to assessment the moisture content by wetted the soil from dry to saturation conditions. The results showed that the three water spectral indices $R_{960} / R_{940}, R_{970} / R_{940}$ and $R_{970} / R_{900}$ showed close and highly significant associations with moisture content of sandy soil, and coefficients of determination reach up to $R^{2}=0.98$. The three water spectral indices $R_{878} / R_{862}, R_{956} / R_{926}$ and $R_{1056} / R_{994}$ showed close and highly significant associations with moisture content of sandy loam soil, and coefficients of determination reach up to $R^{2}=0.84$. As well as the three water spectral indices $R_{956} / R_{924}, R_{956} / R_{926}$ and $R_{956} / R_{9284}$ showed close and highly significant associations with moisture content of clay soil, and coefficients of determination reach up to $R^{2}=0.86$. In conclusion, the use of spectral remote sensing may open an avenue in irrigation management for fast, high-throughput assessments of water status of soil samples.
\end{abstract}

Key words: irrigation, precision, soil water content, remote sensing, precision agriculture, spectral indices,

\footnotetext{
$\overline{{ }^{1} \text { Assoc. Prof. of Agric. Eng., Evaluation of Natural Resources Department, }}$ Environmental Studies and Research Institute, Sadat City University.

${ }^{2}$ Lecturer of Agric. Eng., Faculty of Agric., Mansoura University.
} 


\section{INTRODUCTION}

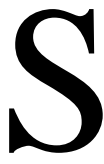
oil moisture is a main variable in land surface hydrology. Soil moisture has very important implications for agriculture, ecology, wildlife, and public health and is probably (after precipitation) the most important connection between the hydrological cycle and life animal, plant, and human. Soil moisture information has been used for irrigation management, site-specific management of diseases and pests, and improving crop yield prediction. In arid and semiarid watersheds, soil moisture content has been used as a surrogate indicator of general plant health. Applied application of soil moisture information is the determination of mobility with lightweight vehicles. The gravimetric method is one of the most simple and intensive way of it. However, more progressive technologies are widespread to detect water management. For example tensiometers, which shows the matrix potential of soils based on the soil moisture content (Tóth, 1995). Another common method to determine soil water content is the measurement of the spread velocity of waves in soil. These methods include the "Time Domain Reflectometry" (TDR) method which is based on determination of the radio-frequency electromagnetic wave propagation velocity (Rajkai, 2004). These methods are time-consuming and require numerous observations to characterize a field. Likewise, for detecting water relation and salinity parameters in the soil, numerous observations are required to characterize a field. In addition, classical methods are unsuitable to tracking frequent changes in environmental conditions, which requires rapid measurements (Elsayed et al., 2015; El-Hendawy et al. 2015; Richbeck et al., 2016). In contrast, the techniques of based ground remote sensing such as passive reflectance sensor could potentially contribute to enhance selection procedures of water status because they are very cost-effective, allow for rapid measurements with non-invasive sampling. From the remote sense techniques, a passive reflectance sensor was used in this study. The passive sensor systems depend on sunlight as a source of light in contrast to active sensors, which are equipped with light-emitting components that provide radiation in specific waveband regions (Kipp et al. 2014). Passive sensors allow hyperspectral information of target to be obtained in the visible and near-infrared range. In one of the earliest reports, Woolley 
(1971) identified the visible spectra (VIS; $400-700 \mathrm{~nm}$ ) as being suitable for this purpose. Reflectance changes in the near infrared region (NIR; $700-1,300 \mathrm{~nm}$ ) can also be used for the detection of water in biological samples because the NIR penetrates more deeply into the measured structures than middle infrared (SWIR; 1,300 - 2,500 nm). As such, the reflectance indicates the water content more of the entire sample rather than of water located in the uppermost layers (Peñuelas et al. 1993). In the SWIR, the strongest absorption properties of water molecules are found at $1,450,1,940$, and 2,500 $\mathrm{nm}$ (Carter 1991). It is a well-known that the reflectance of soil generally increases with the wavelength. The rate of this is related to other physical and chemical properties of soil. Based on the earlier results, organic matter content, moisture content, parent material, the presence of colour chemical, soil texture, size of the soil particles and salt content are the most important factors which determine the reflectance. These factors are complex, changeable and there is relationship among them. General observations that increase in organic matter and water content of the soil decrease the reflectance properties in the wavelength range of 0.4-2.5 microns. Humus is the major determinant of the reflectance, if the humus content of soil is more than $2 \%$. The reflectance decrease in 1.3-1.5 and 1.75-1.95 micron intervals is the result of the absorption of water content in soil. The soil surface moisture content is one of most rapidly changing parameters, which is depending on physical, chemical and biological qualities of soils and environmental effects (Csornai-Dalia, 1991). The main effect of moisture is observed on the middle infrared (MIR) range (Belényesi, 2008). The reflectance value (from soil reflectance curve) is mainly influenced by soil moisture and mineral structure. Furthermore, the reflectance increases within higher wavelengths. Accurate spectral profile of a mineral can be determined only in laboratory. Currently, there are so called spectral libraries, where the typical spectral reference curves with absorption peaks and minimums of different minerals are stored (Belényesi, 2008)

Therefore, the purpose of this work was to (i) evaluate the performance of passive sensor to assess the moisture content of different soils types, (ii) to test which spectral indices can be used to estimate the moisture content 
(iii) to build a contour map analysis for all wavelengths of the hyperspectral passive sensor (from 302 to1048 nm).

\section{MATERIAL AND METHODS}

\subsection{Experimental information}

The experiments were conducted at the Research Station of Sadat City University in Egypt (Latitude: N 30 2' 41.185", Longitude: E 31 ${ }^{\circ} 14^{\prime}$ $\left.8.1625^{\prime \prime}\right)$. The three different soils textures (sandy, sandy loam and clay) were used. Sandy soil contains (97\% sand, $2 \%$ silt, and $1 \%$ clay), sandy loam soil contains ( $72.8 \%$ sand, $19.3 \%$ silt, and $7.9 \%$ clay) and clay soil contains ( $40.6 \%$ sand, $18.4 \%$ silt, and $41 \%$ clay).The spectral profiles of the soil samples were measured at various moisture conditions. Soil samples were dried to constant weight at $105^{\circ} \mathrm{C}$ and $100 \mathrm{~g}$ samples were saturated by $2 \mathrm{ml}$ distilled water ( 2.5 percent of dry weight) until full saturation for sandy soil, 2.5 for sandy loam and $5 \mathrm{ml}$ for clay soil until wilting point and after that $2.5 \mathrm{ml}$ until full saturation. Each treatment has three replicates. In parallel, spectral profiles of wetted soil was regularly measured at all wetted stage. First of all, spectral properties of the dry soil samples were measured.

\subsection{Spectral reflectance measurements}

A passive bi-directional reflectance sensor (tec5, Oberursel, Germany), measuring at wavelengths between 302-1148 $\mathrm{nm}$ with a bandwidth of 2 $\mathrm{nm}$, was used. The handheld FieldSpec sensor consists of two units: one unit is linked with a diffuser and measures the light radiation as a reference signal, while the second unit measures soil reflectance with a fiber optic (Elsayed et al., 2015). The aperture of the optics was $12^{\circ}$ and the field of view was $0.1 \mathrm{~m}^{2}$ from half meter distance. Three spectral measurements were taken for treatment. Spectral measurements of three soils types under different moisture content were taken within 20 minutes on a sunny period to avoid changes in sun radiation, and the fiber optics at nadir direction were positioned a height above the soil samples. With the readings from the spectrometer unit, the soil samples ' reflectance was calculated and corrected with a calibration factor obtained from a reference gray standard. 


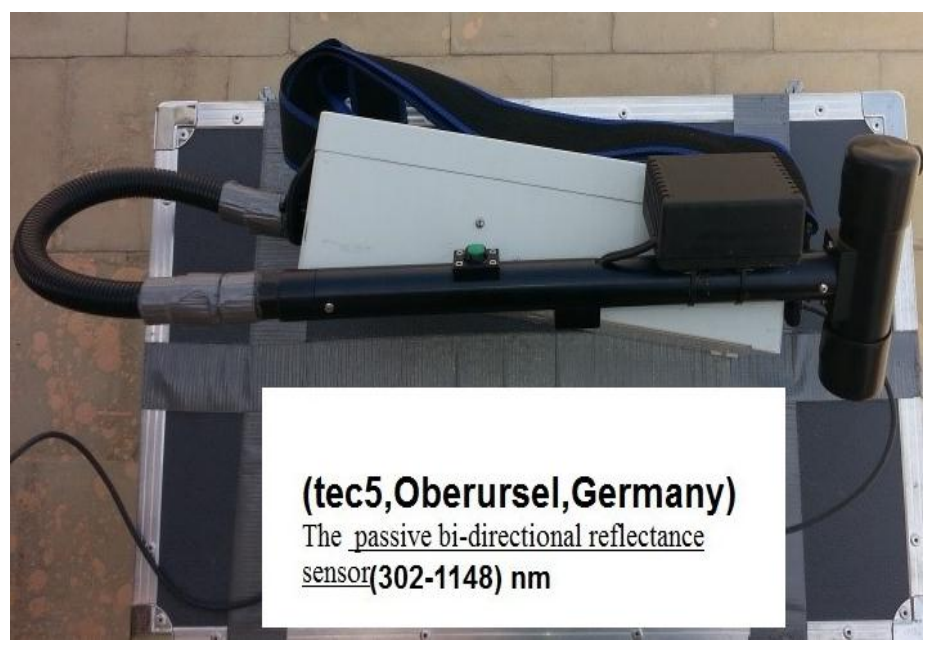

Fig.1. A passive bi-directional reflectance sensor measuring wavelengths between $302-1148 \mathrm{~nm}$ coupled with GPS unit.

\subsection{Statistical analysis}

\subsubsection{Selection of spectral reflectance indices}

In Table 1 eight spectral indices from different sources are listed with references. In this study, both known and novel indices were calculated and tested. A contour map analysis for all wavelengths of the hyperspectral passive sensor (from 302 to1148 nm) was used to select some spectral indices, which generally presented more stable and strong relationships with moisture content of the three soils. All possible dual wavelengths combinations were evaluated based on a contour map analysis for the hyperspectral passive sensor. Contour maps are matrices of the coefficients of determination of soil moisture content with all possible combinations of binary, normalized spectral indices. The $\mathrm{R}$ package "lattice" from the software $\mathrm{R}$ statistics version 3.0.2 (R foundation for statistical computing 2013) was used to produce the contour maps from the hyperspectral reflectance readings, while twelve wavelengths $(862,878,900,924,926,928,940,956,960,970,994$ and $1056 \mathrm{~nm}$ ) were used to calculate reflectance indices, as indicated in Table 1.

\subsubsection{Modeling of measurements}

Sigmaplot for Windows v.12 (Systat software Inc., Chicago) and SPSS 22 (SPSS Inc., Chicago, IL, USA) were used for the statistical analysis. 
Simple linear regressions were calculated to analyze the relationship between the spectral reflectance indices listed in Table 1 and the moisture content of the soil. Coefficients of determination and significance levels were determined; $t$ nominal alpha values of 0.01 and 0.001 were used.

Table 1. Spectral indices, formula and references of different spectral indices used in this study.

\begin{tabular}{lll}
\hline Spectral reflectance & Formula & References \\
\hline $\mathrm{R}_{878}$ and $\mathrm{R}_{862}$ & $\mathrm{R}_{878} / \mathrm{R}_{862}$ & This wor \\
$\mathrm{R}_{956}$ and $\mathrm{R}_{924}$ & $\mathrm{R}_{956} / \mathrm{R}_{924}$ & This work \\
$\mathrm{R}_{956}$ and $\mathrm{R}_{926}$ & $\mathrm{R}_{956} / \mathrm{R}_{926}$ & This work \\
$\mathrm{R}_{956}$ and $\mathrm{R}_{928}$ & $\mathrm{R}_{956} / \mathrm{R}_{928}$ & This work \\
$\mathrm{R}_{960}$ and $\mathrm{R}_{940}$ & $\mathrm{R}_{960} / \mathrm{R}_{940}$ & Elsayed et al., 2011 \\
$\mathrm{R}_{970}$ and $\mathrm{R}_{940}$ & $\mathrm{R}_{970} / \mathrm{R}_{940}$ & This work \\
$\mathrm{R}_{970}$ and $\mathrm{R}_{900}$ & $\mathrm{R}_{970} / \mathrm{R}_{900}$ & Peñuelas et al., 1997 \\
$\mathrm{R}_{1056}$ and $\mathrm{R}_{994}$ & $\mathrm{R}_{1056} / \mathrm{R}_{964}$ & This work \\
\hline
\end{tabular}

\section{RESULTS AND DISCUSSION}

Soils can be examined on the basis of spectral data, using such methods with which the reflected radiation can be divided into a large number of (several hundreds) small spectral channel (some $\mathrm{nm}$ ). Based on the spectral characteristics of the soils, or the different index numbers calculated from hyperspectral data water content of soils can be well characterized. Different soil textures possess different spectral characteristics. The difference in soil types (the sandy, sandy loam and clay) manifested mainly in the extent of reflectance. The reflectance curves of sand and sandy loam soil presented higher values of reflectance compare to clay soil at visible and near infrared regions. Soils reached their maxima at the NIR range (Figure 2). There were significant differences between spectral characteristics of sandy, sandy loam and clay soils and these results agree with Nagy et al. (2014). 


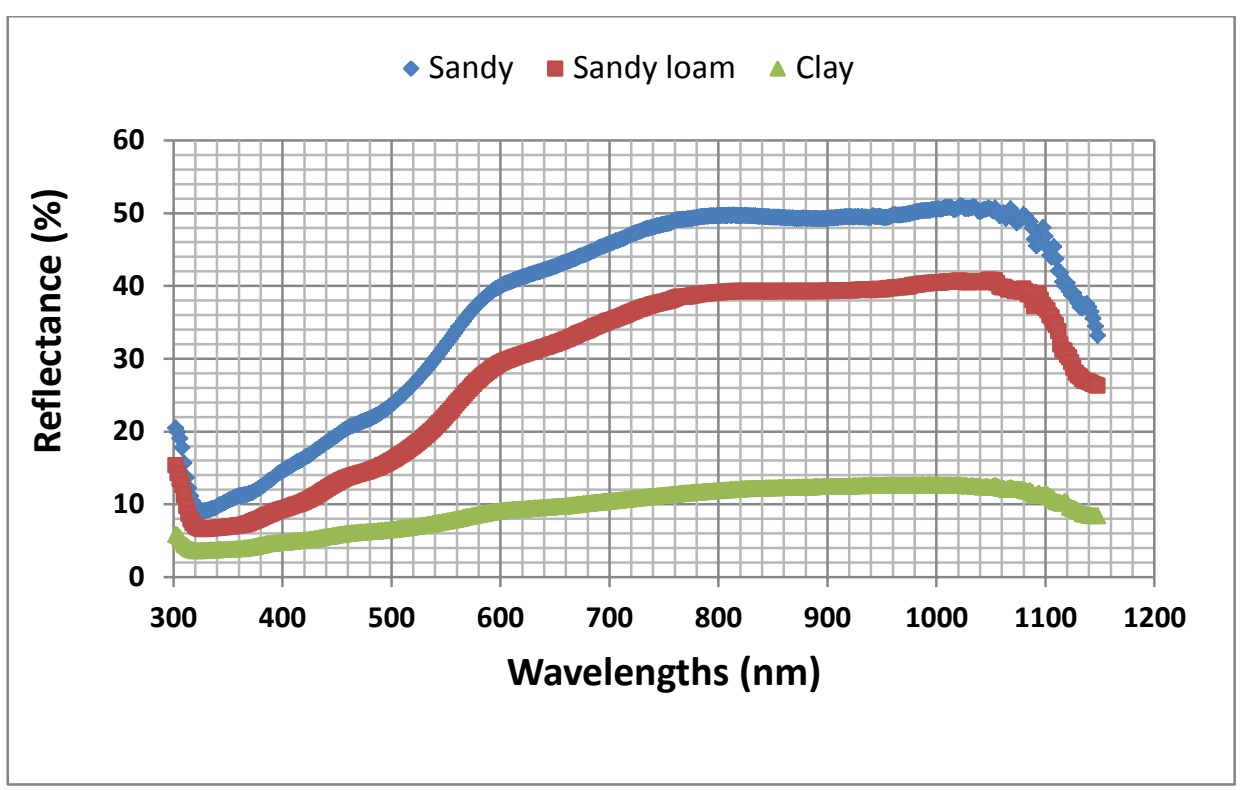

Fig.2. Spectral reflectance curves for dry soil of sandy, sandy loam and clay

Analysis of the impact of soil moisture on the spectral properties showed that regardless soil textures the increases of moisture affected the total reflectance curve between 400-1148 nm. In parallel with increasing moisture content, the reflectance showed trend like rising to higher wavelengths (Figures 3, 4, 5). The spectral properties of the soils are different in the 350-830 $\mathrm{nm}$ range from the measured ones with the previous instrument and other studies (Bowers et al. 1965, Nagy et al., 2009). While in other studies, a continuous increase is described in reflectance at the $350-830 \mathrm{~nm}$ region, in this case the initial rapid increase at $450 \mathrm{~nm}$ followed by a significant valley with minimum value at 590$610 \mathrm{~nm}$, and then a significant increase was detected (Nagy et al., 2014). Concerning the reliability of our results, the effects of moisture content on spectral properties were analyzed at the wavelength range between 302 and $1148 \mathrm{~nm}$. Almost of wavelengths near infrared regions were the most sensitive to moisture. Similarly, to each wavelength, the moisture content decreases the reflectance of the sensitive ranges as well. 


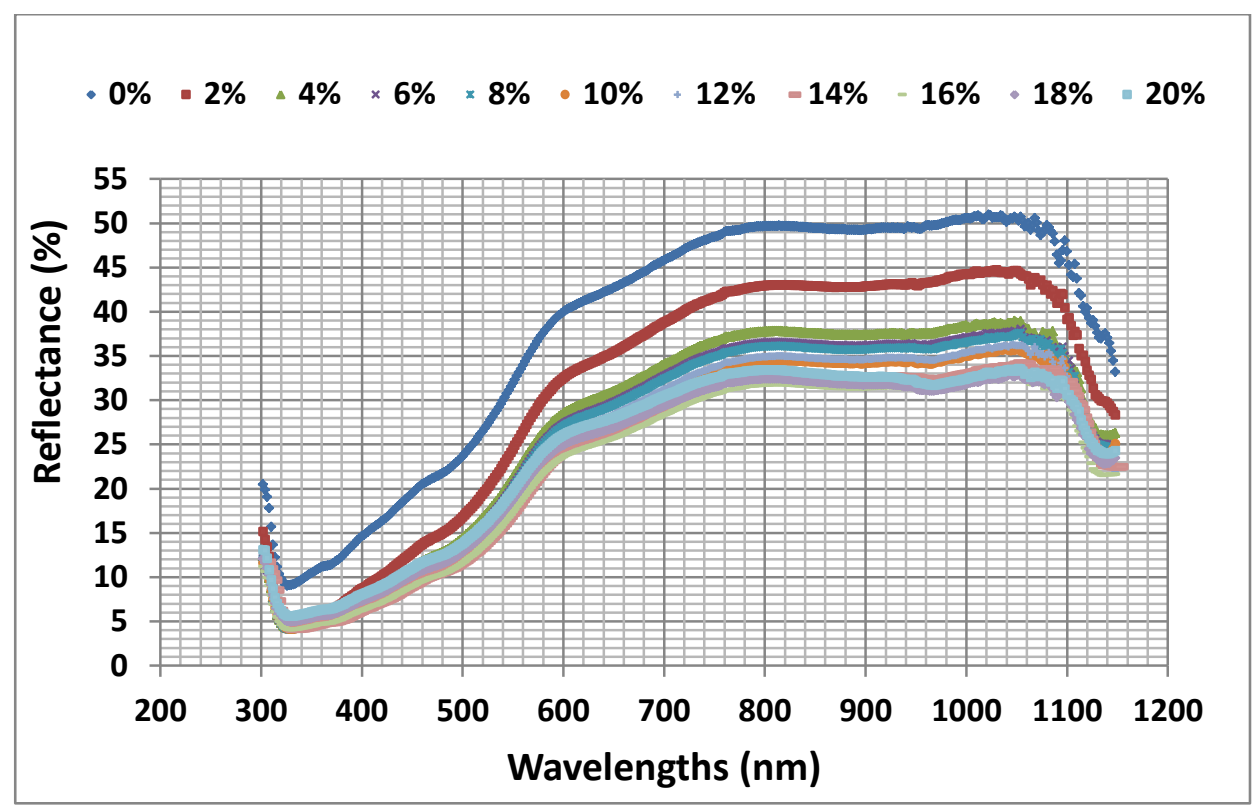

Fig.3. Spectral reflectance curves for sandy soil under different moisture content $(\%)$

A contour map analysis produced the coefficients of determination $\left(\mathrm{R}^{2}\right)$ of the measurements for all dual wavelengths combinations from 302 to $1148 \mathrm{~nm}$ as spectral index. Contours of the matrices of the hyperspectral passive sensor presented generally more distinct relationships with moisture content. The contour map analysis of the relationship between the spectral indices with moisture content of sandy, sandy loam and clay were used and shown in (Figs. 6, 7, 8). A contour map presented a larger range of indices with similar wavelength contain information relevant for the all biochemical parameters. The contours of the matrices of the spectral passive sensor presented stronger relationships between moisture content of the soil with visible, near infrared wavelengths and the combination of visible and near infrared wavelengths. The averages of the correlation matrices resulting from the measurements, indicated by the coefficients of determination $\left(\mathrm{R}^{2}\right)$ for all dual wavelengths combinations of $500-1000 \mathrm{~nm}$ as spectral indices for all measurements, presented higher $\mathrm{R}^{2}$-values compared to all other two wavelength combinations 


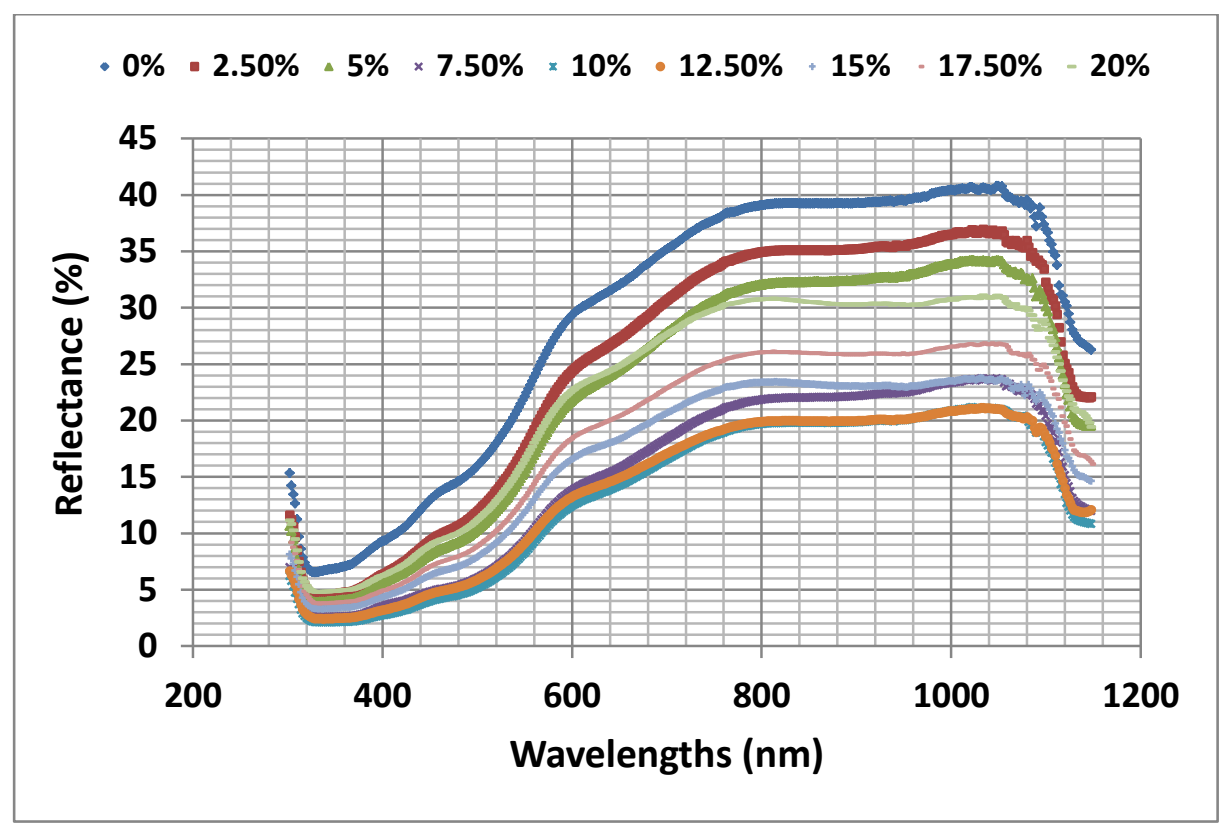

Fig.4. Spectral reflectance curves for sandy loam soil under different moisture content $(\%)$

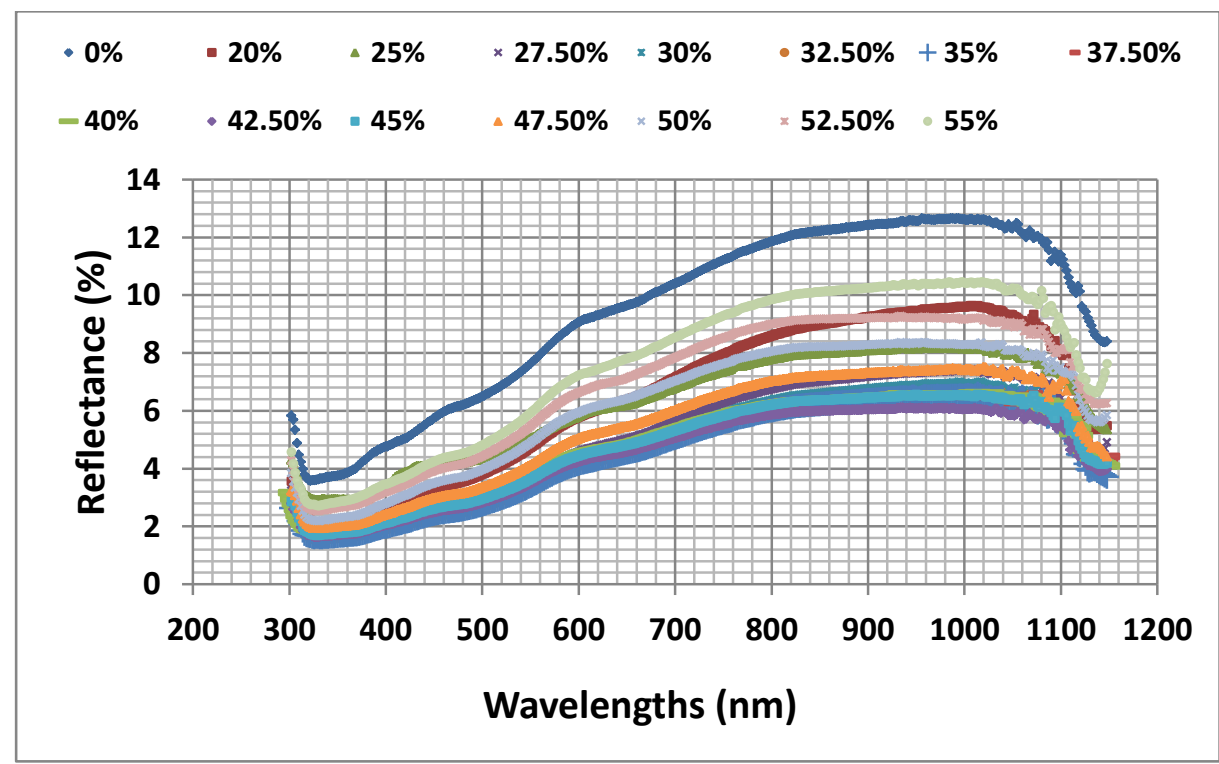

Fig.5. Spectral reflectance curves for clay soil under different moisture content $(\%)$ 


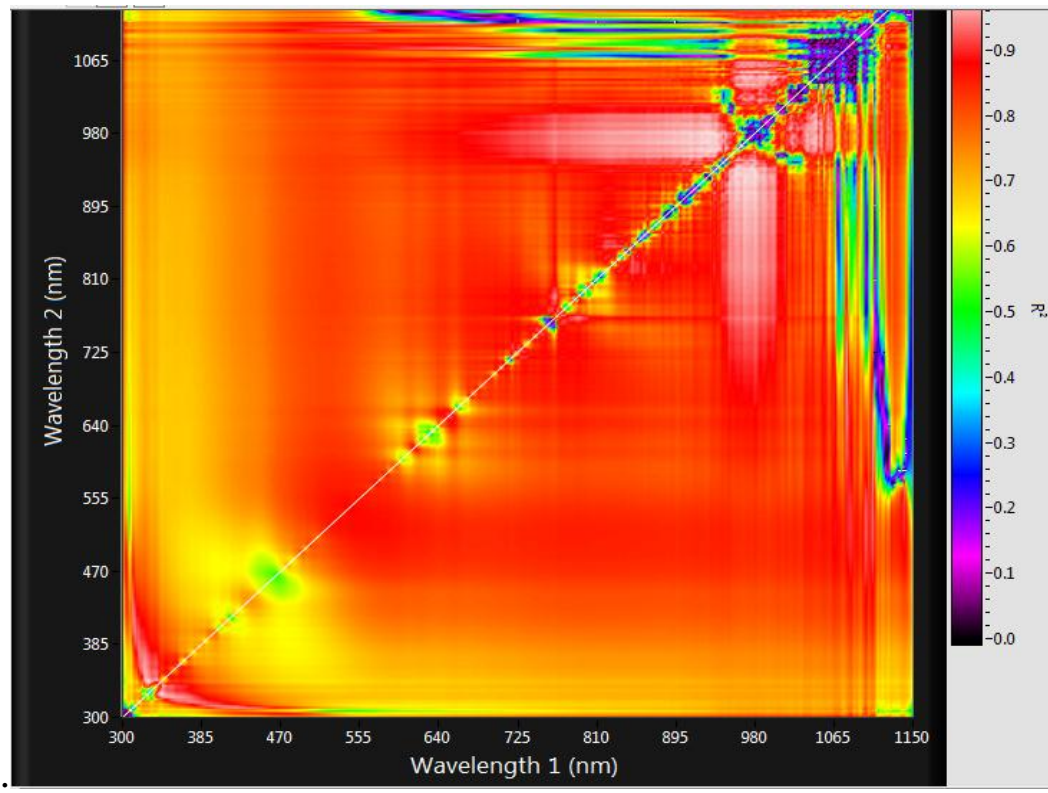

Fig. 6. Correlation matrices (contour maps) showing the coefficients of determination $\left(\mathrm{R}^{2}\right)$ for all dual wavelength combinations in the 302-1148 $\mathrm{nm}$ range (as a spectral index) of the hyperspectral passive reflectance sensing with moisture content $(\%)$ of sandy soil.

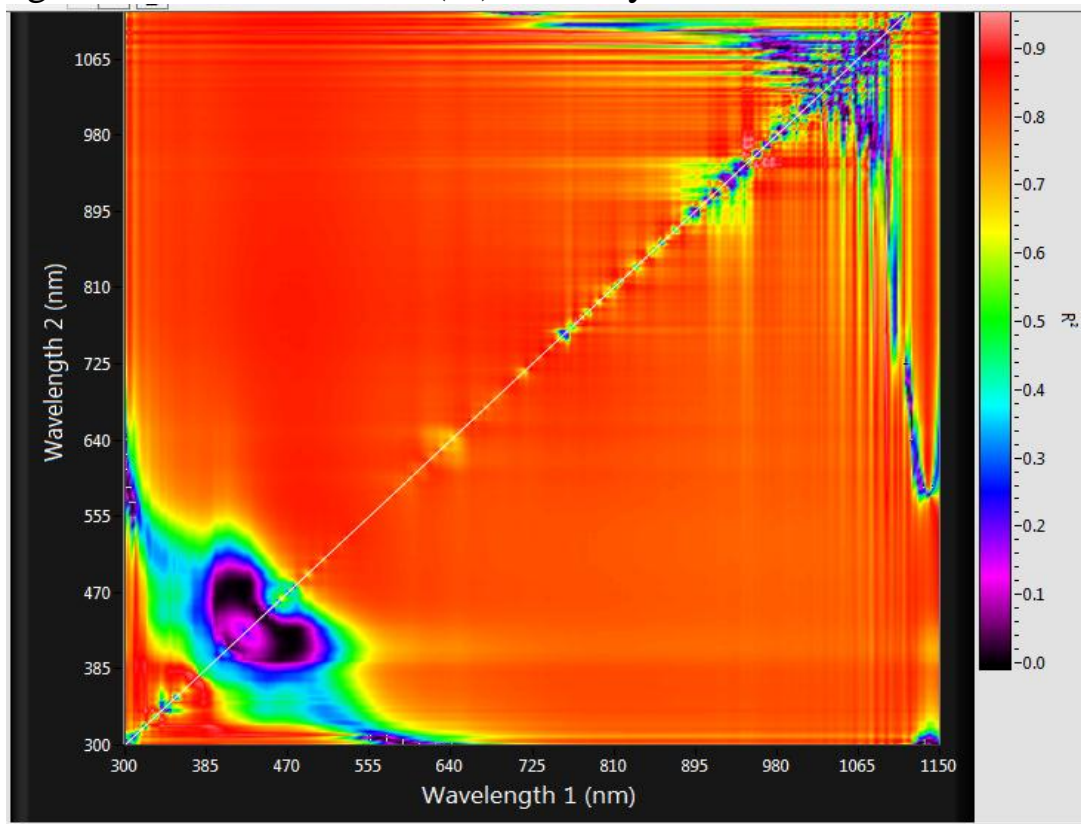

Fig. 7. Correlation matrices (contour maps) showing the coefficients of determination $\left(\mathrm{R}^{2}\right)$ with moisture content $(\%)$ of sandy loam soil. 


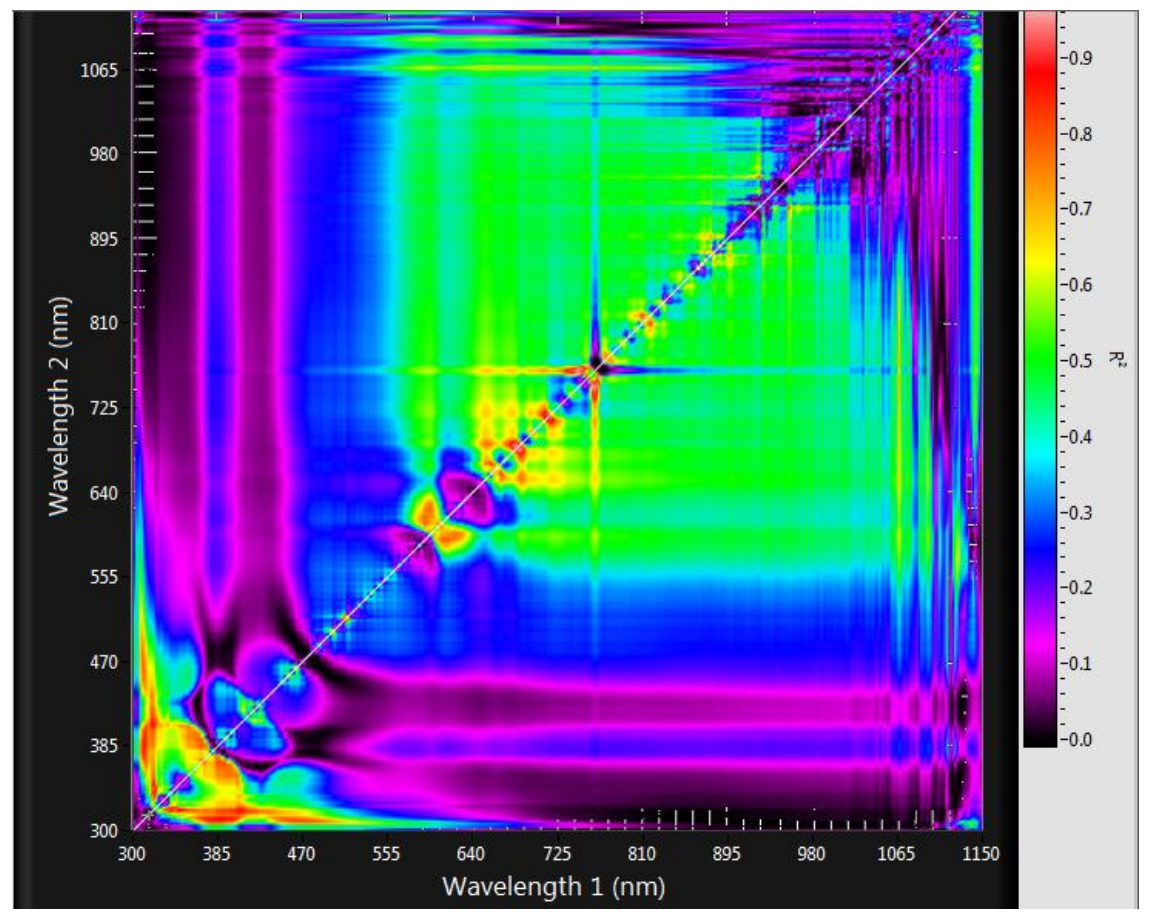

Fig. 8. Correlation matrices (contour maps) showing the coefficients of determination $\left(\mathrm{R}^{2}\right)$ with moisture content $(\%)$ of clay soil.

In Figs. 9, 10 and 11 eight spectral reflectance indices were significantly related to the moisture content of different soil. Statistically significant relationships between all spectral reflectance indices derived from the visible and near infrared NIR region were found. Generally, The results showed that the three water spectral indices $R_{960} / R_{940}, R_{970} / R_{940}$ and $\mathrm{R}_{970} / \mathrm{R}_{900}$ showed close and highly significant associations with moisture content of sandy soil, and coefficients of determination reach up to $\mathrm{R}^{2}=$ 0.98. The three water spectral indices $R_{878} / R_{862}, R_{956} / R_{926}$ and $R_{1056} / R_{994}$ showed close and highly significant associations with moisture content of sandy loam soil, and coefficients of determination reach up to $\mathrm{R}^{2}=0.84$. As well as the three water spectral indices $R_{956} / R_{924}, R_{956} / R_{926}$ and $\mathrm{R}_{956} / \mathrm{R}_{928}$ showed close and highly significant associations with moisture content of clay soil, and coefficients of determination reach up to $\mathrm{R}^{2}=$ 0.86 . 

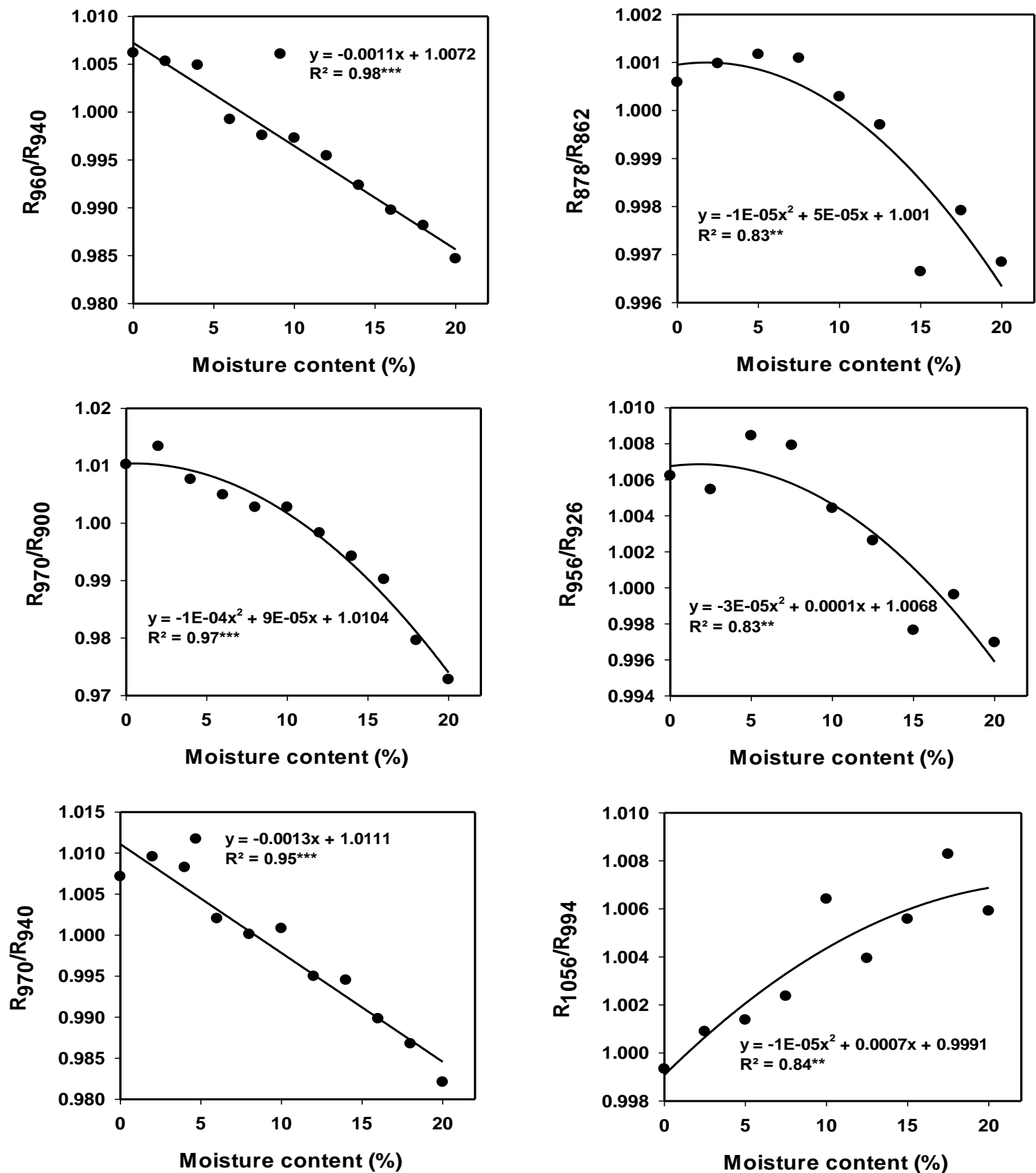

Fig. 9. The relationship between the spectral indices $\left(\mathrm{R}_{960} / \mathrm{R}_{940}, \mathrm{R}_{970} / \mathrm{R}_{900}\right.$ and $\mathrm{R}_{970} / \mathrm{R}_{940}$ ) with moisture content (\%) of sandy soil.

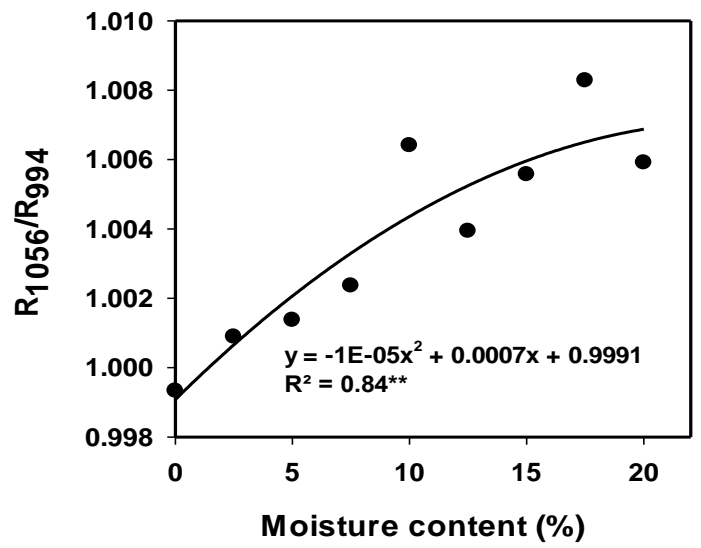

Fig. 10. The relationship between the spectral indices $\left(\mathrm{R}_{878} / \mathrm{R}_{862}, \mathrm{R}_{956} / \mathrm{R}_{926}\right.$ and $\left.\mathrm{R}_{1056} / \mathrm{R}_{994}\right)$ with moisture content (\%) of sandy loam soil. 

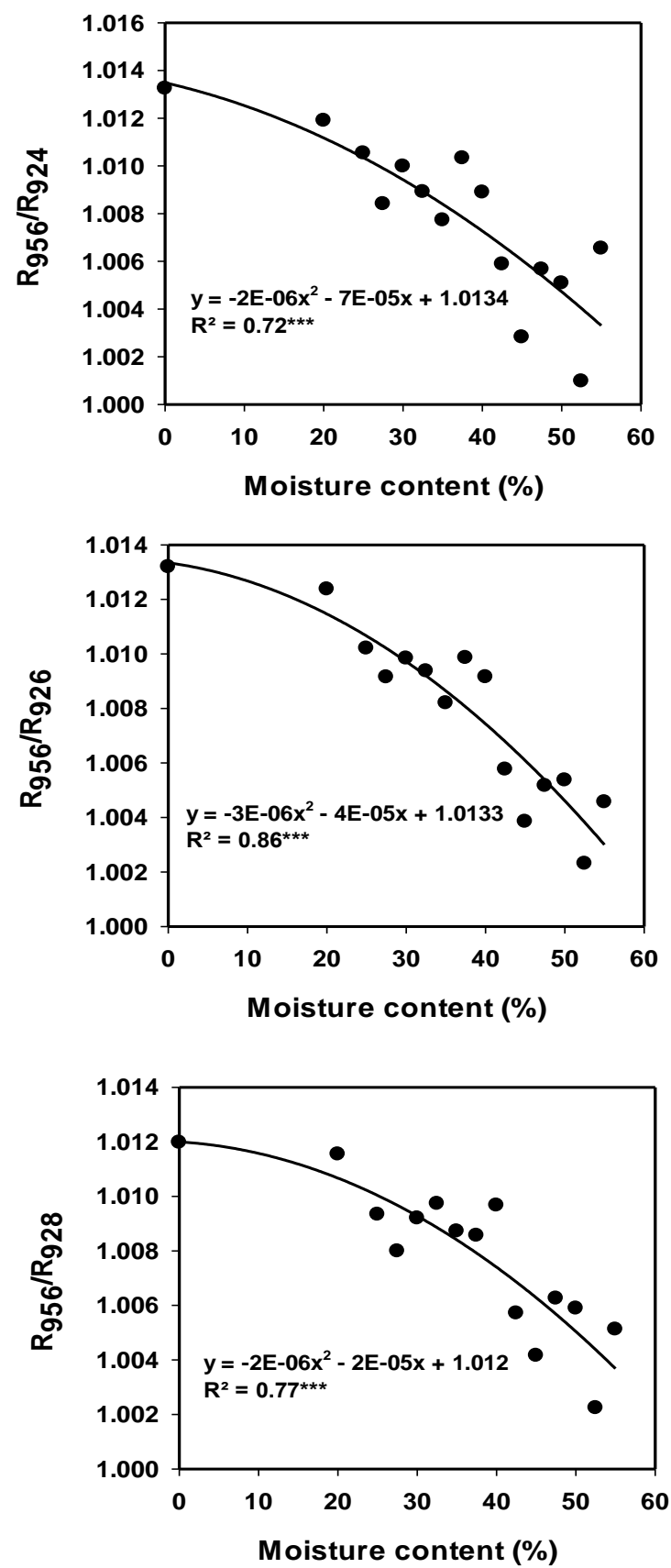

Fig. 11. The relationship between the spectral indices $\left(R_{956} / R_{924}, R_{956} / R_{926}\right.$ and $\mathrm{R}_{956} / \mathrm{R}_{928)}$ with moisture content (\%) of clay soil. 


\section{CONCLUSIONS}

From the above results, it could be concluded that the selected spectral indices seem to be good indicators for detect the moisture content of different soil types and it is useful method for irrigation management for fast, high-throughput assessments of water status of soil samples. The method of measuring soil moisture by spectral properties and using the developed spectral indices provides the fast determination of water content of a certain soil. As a result, such up to date information can be obtained on water supply, which is essential for irrigation scheduling, and from agro technical point of view. Additionally, it is suitable for the calibration of airborne hyperspectral images.

\section{REFERENCES}

Belényesi, M., Kristóf, D., Magyari, J. 2008. Távérzékelés a környezetgazdálkodásban Elméleti jegyzet, Egyetemi jegyzet SZIE Mezőgazdasági- és Környezettudományi Kar Gödöllő, 78.

Bowers, S.A., Hanks, R.J., 1965. Reflection of radiant energy from soil, Soil Science, 100:130-138.

Carter, G.A., 1991. Primary and secondary effects of water content on the spectral reflectance of leaves. American Journal of Botany, 78, 916924.

Csornai, G. and Dalia, O., 1991. Távérzékelés Kézirat, Erdészeti és Faipari Egyetem Földmérési és Földrendezői Főiskolai Kar, Székesfehérvár.

El-Hendawy, S., Al-Suhaibani, N., Salem, A., Ur Rehman, S. and Schmidhalter, U., 2015. Spectral reflectance indices as a rapid nondestructive phenotyping tool for estimating different morphophysiological traits of contrasting spring wheat germplasms under arid conditions. Turk. J. Agric. For. 39: 572-587.

Elsayed, S., Rischbeck, P. and Schmidhalter, U., 2015. Comparing the performance of active and passive reflectance sensors to assess the 
normalized relative canopy temperature and grain yield of droughtstressed barley cultivars. Field Crop Res. 177: 148-160.

Kipp, S., Mistele, B., Schmidhalter, U., 2014. The performance of active spectral reflectance sensors as influenced by measuring distance, device temperature and light intensity. Computer Electron. Agric. 100, 24-33.

Nagy, A. and Tamás, J., 2009. Integrated airborne and field methods to characterize soil water regime. [In: Celkova, A. (ed.) Proceedings of peer-reviewed contributions, Transport of water, chemicals and energy in the soil-plant-atmosphere system] Institute of Hydrology, Slovak Academy of Sciences, Bratislava, 412-420.

Nagy, A., Riczu, P., Gálya, B. and Tamás, J., 2014. Spectral estimation of soil water content in visible and near infra-red range. Eurasian Journal of Soil Science 3, 163 - 171.

Peñuelas, J., Filella, I. and Serrano, L. 1993. The reflectance at the 950$970 \mathrm{~nm}$ region as an indicator of plant water status. International Journal of Remote Sensing, 14, 1887-1905.

Peñuelas, J., Isla, R., Filella, I. and Araus, J.L., 1997. Visible and near infrared reflectance assessment of salinity effects on barley. Crop Sci. 37: 198-202.

Rajkai, K. 2004. A víz mennyisége, eloszlása és áramlása a talajban. MTA TAKI Budapest.

Rischbeck P., Elsayed S., Mistele B., Barmeier G., Heil K. and Schmidhalter U. 2016. Data fusion of spectral, thermal and canopy height parameters for improved yield prediction of drought stressed spring barley. Eur. J Agron. 78: 44-59.

Tóth, Á. 1995. Az esőszerű és a mikroöntözés gyakorlata.KITE Rt. Nádudvar. 118.

Woolley, J. T. 1971. Reflectance and transmittance of light by leaves. Plant Physiology, 47, 656- 662. 
الملخص العربى

استخدام الرصد الأرضي للاستشعار عن بعد في تقدير المحتوى الرطوبي لأنواع مختلفة من التربية

\section{د/ صلاح السيد محمد' و د/ محمد ابراهيم غازي '}

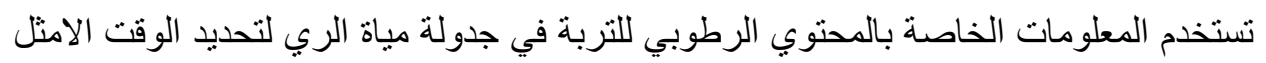

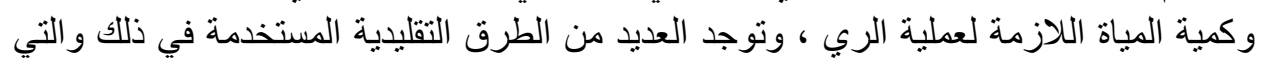
تسنهلك الكثير من الوقت والمجهود.

علي العكس من الطرق التقليدية فإن الإستشعار عن بعد الطيفي يعطي معلومات سريعة و يغطي

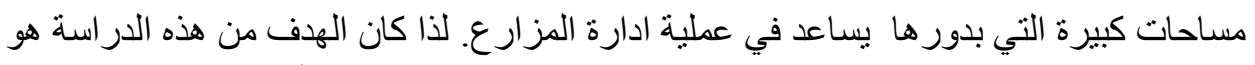

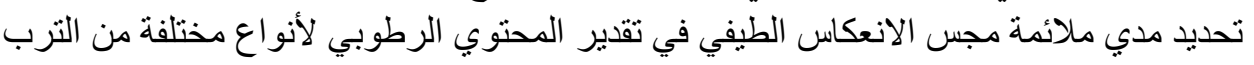

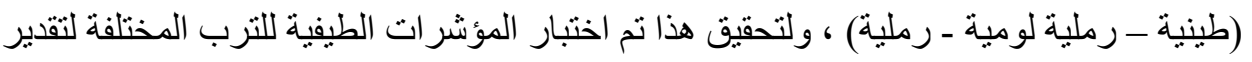
المحتوي الرطوبي عند مستويات مختلفة من الرطوبة بداية من الجفاف التام وحتي التشبع.

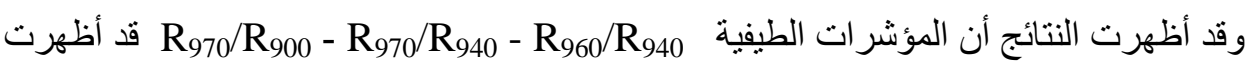

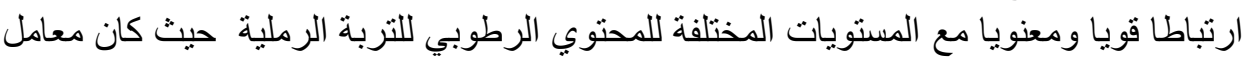

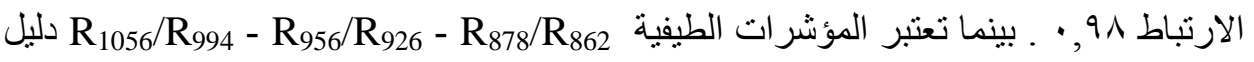

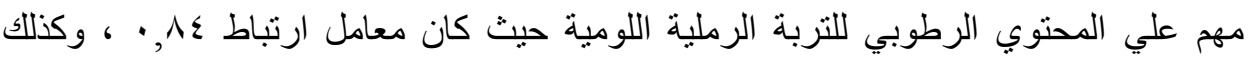

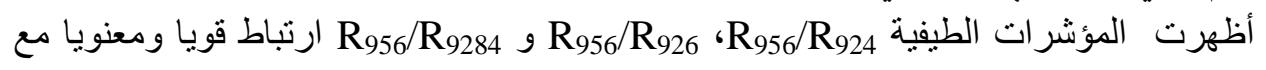

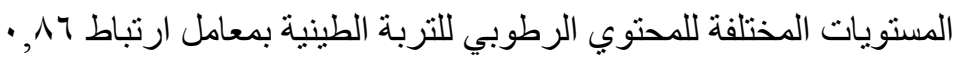

وفي الخلاصة فإن الاستشعار عن بعد الطبفي يفتح المجال لاستخدامه كآداه من ادوات التوبة ادارة مياة

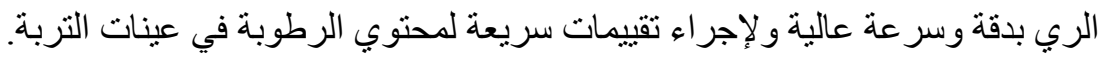

'أستاذ مساعد الهندسة الزراعية ـ معهد الدراسات والبحوث البيئية ـ جامعة مدينة السادات.

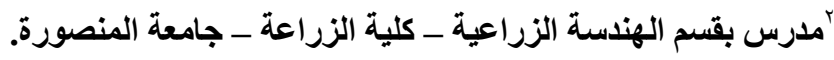

